\title{
MANAJEMEN PEMASARAN ONLINE MAKARONI HUHHAH YOGYAKARTA
}

\author{
Suprono Wahyujatmiko ${ }^{1}$, Irwan Yon Hadi $^{2}$
}

\author{
${ }^{1}$ Sekolah Tinggi Ilmu Ekonomi Isti Ekatana Upaweda Yogyakarta \\ ${ }^{2}$ Sekolah Tinggi Ilmu Ekonomi Isti Ekatana Upaweda Yogyakarta \\ Yonhadi8@gmil.com
}

\begin{abstract}
Semakin banyaknya pelaku usaha dalam bisnis makaroni, maka persaingan juga semakin ketat. Dibutuhkan manajemen pemasaran, kreativitas dan inovasi guna mendapatkan konsumen lebih banyak lagi. Makaroni Huhhah menggunakan media sosial instagram untuk melakukakn promosi. Penelitian ini bertujuan untuk mendiskripsikan manajemen pemasaran online melalui instagram, mulai dari perencanaan, pengorganisasian, pelaksanaan dan evaluasi oleh Macaroni Huhhah dalam meningkatkan penjualan pada tahun 2017.

Jenis penelitian ini bersifat deskriptif kualitatif Pengumpulan data menggunakan teknik obervasi dan wawancara mendalam untuk mencari informasi umum yang akurat tentang manajemen pemasaran melalui media online. Teknik analisis yang digunakan dalam penelitian ini adalah model interaktif models of analysis atau analisis interaktif. Keabsahan data dalam penelitian ini dilakukan dengan teknik triangulasi data. Penelitian dilaksanakan di kantor pusat manajemen Macaroni Huhhah Jogja.

Hasil penelitian menunjukkan bahwa manajemen pemasaran Makaroni Huhhah secara online melalui instagram dilakukan dengan terlebih dulu membuat perencanaan lalu diimplementasikan. Agar mencapai tujuannya, manajemen pemasaran dilakukan dengan tetap melakukan pengawasan dan pengendalian terhadap kegiatan pemasaran. Perencanaan pemasaran meliputi penentuan segmen pasar, pemlihan saluran komunikasi pemasaran, penentuan tujuan pemasaran, penentuan strategi pemasaran yaitu menggunakan instagram, dan menentukan bauran pemasaran. Implementasi meliputi semua aktivitas untuk merealisasikan rencana pemasaran yang sudah disusun. Strategi pemasaran yang dilakukan yaitu dengan memanfaatkan fitur yang ada di instagram yaitu like, comment, biodata, follower, caption, hashtag, dan give away. Pengawasan dan pengendalian dilakukan dengan cara melihat like, komentar ataupun direct massage. Jika respon dirasa kurang, maka admin@makaronihuhhahjogja akan mengunggah foto produk dengan caption yang lebih menarik dan menggunakan hashtag yang relevan dan dengan jumlah hashtag yang lebih banyak.
\end{abstract}

Kata kunci : Manajemen, Pemasaran, Instagram

(C) 2018 JBTI. All rights reserved

Article history : received 2 Agt 2018; revised 21 Agt 2018; accepted 20 Sep 2018

\section{PENDAHULUAN}

Makaroni merupakan camilan yang sedang naik daun karena banyak digemari oleh konsumen terutama kalangan remaja. Bisnis makaroni telah menarik banyak pelaku usaha untuk ikut terjun dalam bisnis camilan dari makaroni ini. Mulai dari pemain besar yang telah lama ada hingga pemain skala rumahan. Menariknya, semua merk makaroni dari banyak pelaku usaha memasarkan makaroni secara online. Studi pendahuluan di situs internet dengan menuliskan kata kunci makaroni yogyakarta, maka akan muncul begitu banyak merk makaroni. Hal ini menunjukkan semakin ketatnya persaingan bisnis camilan makaroni. Namun, makaroni yang paling terkenal adalah makaroni Ngehe diikuti oleh sejumlah merk follower seperti Macaroni 
Factory, Macaroni Huhhah dan Macco Makaroni serta produk-produk macaroni sejenis yang tidak begitu dikenal.

Ngehe termasuk market leader bagi brand makaroni lainnya seperti Makaroni Factory dan Macco Makaroni. Huh-hah termasuk pendatang baru dalalm bisnis makaroni. Sejumlah brand tersebut berebut pasar dengan gencar melakukan promosi melalui berbagai media, terutama media sosial seperti Facebook, instagram, twitter, kaskus, blog dan toko online. Media online terutama media sosial dipilih karena media sosial dapat menampilkan bauran promosi sekaligus sebagaimana pada promosi offline. Rangkuti (2009) menjelaskan bahwa promosi online menampilkan adevertising, direct marketing, sales promotion, public relation, dan personal selling. Produk yang dipasang pada wall facebook memperlihatkan bahwa produk bersangkutan sedang diiklankan.

Direct marketing tampak pada nomor telepon yang dipasang di laman facebook Makaroni Ngehe. Pada akun instagram Makaroni Huh-hah mencantumkan nomor wa, dan sejumlah alamat outlet di Yogyakarta. Public relation tampak dari sejumlah meme yang diposting di facebook maupun instagram. Sales promotion Makaroni Huhhah tampak pada postingan meme yang menyebutkan voucher discount $18 \%$.

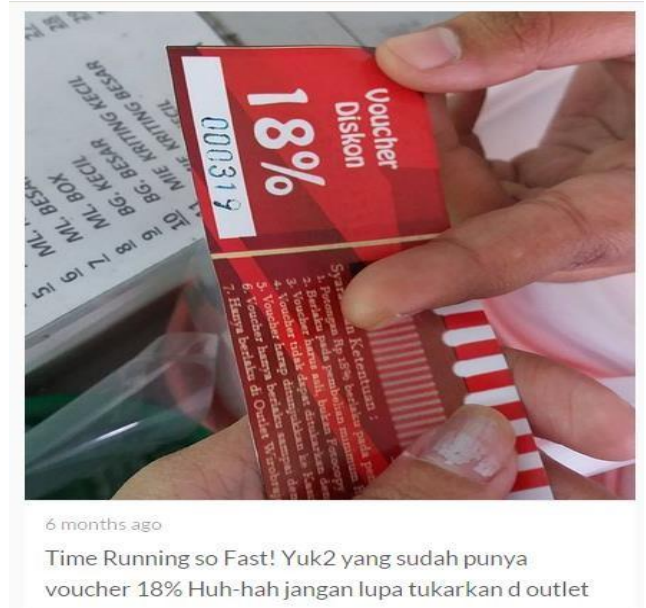

Gambar 1. Sales Promotion pada halaman Instagram Makaroni Huhhah tahun 2018

Meme dengan kalimat Yuk2 yang sudah punya voucher $18 \%$ merupakan bentuk promosi untuk meningkatkan penjualan. Tampilan meme tersebut akan lebih menarik pelanggan untuk membeli lebih banyak.

Public relations tampak pada fiture yang dipasang seperti photo gallery, guestbook online, atau recommend site to a friend. Public relations penting dilakukan agar hubungan baik dengan pelanggan tetap terjaga, misalnya dengan memposting meme marhaban ya ramadhan di bawah ini.

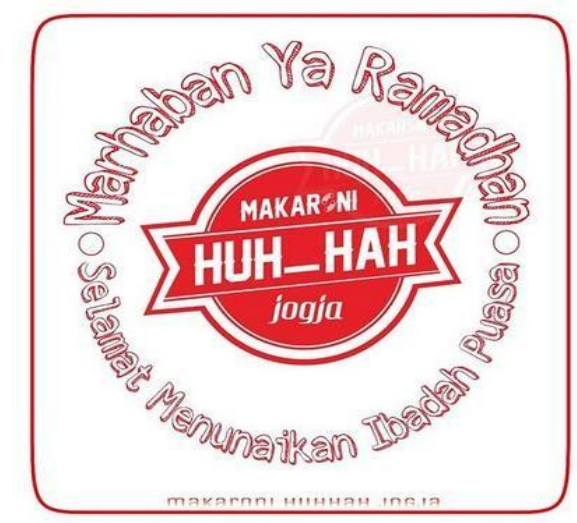

Gambar 2. Ucapan selamat menunaikan ibadah puasa untuk Menjaga Hubungan baik dengan Publik 
Fiture online booking facility memperlihatkan adanya personal selling. Menurut Rangkuti (2009), personal selling di internet ditunjukkan dengan adanya fasilitas guna melakukan penjualan secara online seperti booking, cara pembayaran dan sejenisnya.

Semakin banyaknya pelaku usaha dalam bisnis makaroni, maka persaingan juga semakin ketat. Dibutuhkan manajemen pemasaran, kreativitas dan inovasi guna mendapatkan konsumen lebih banyak lagi. Oleh karena itu perlu ada manajemen pemasaran yang mampu menjangkau lebih banyak konsumen. Media sosial seperti facebook, twitter, IG maupun promosi online lainnya menjadi keharusan agar produknya cepat menjadi viral. Makaroni menjadi viral ketika banyak orang yang bersedia menyampaikan pesan yang sedang dipromosikan. Brand yang unik, tampilan gambar, kemasan produk yang unik dan iklan unik di media sosial diharapkan dapat menarik perhatian konsumen untuk menceritakan tentang camilan makaroni ini.

Penggunaan media sosial sangat tepat karena media ini semakin familiar di semua lapisan masyarakat. Dengan adanya facebook, twitter, blog maupun instragram maka setiap individu dapat terhubung dengan jejaring sosial di dunia maya. Keberhasilan promosi dapat dilihat dari jumlah follower di twitter maupun instagram seperti tampak pada Tabel 1.

Tabel 1. Jumlah Follower di Media Sosial per Juli 2018

\begin{tabular}{|c|c|c|}
\hline Nama Brand & Media Promosi & Follower \\
\hline \multirow{2}{*}{ Makaroni Ngehe } & $\begin{array}{c}\text { Instragram } \\
\text { @ macaroningehe }\end{array}$ & 89.000 \\
\cline { 2 - 3 } & Twitter@ngehe_id & 3.996 \\
\hline \multirow{2}{*}{ Macaroni Huhhah } & $\begin{array}{c}\text { Instragram } \\
\text { @makaronihuhhahjogja }\end{array}$ & 2,019 \\
\cline { 2 - 3 } & $\begin{array}{c}\text { Twitter } \\
\text { @Makaroni_huhhah }\end{array}$ \\
\hline \multirow{2}{*}{ Macco makaroni } & Instragram & 398 \\
\cline { 2 - 3 } & - & - \\
\hline
\end{tabular}

Sumber: website diolah 2018

Posisi makaroni Huhhah sebagai follower dalam bisnis makaroni tidak menyurutkan peluang bisnis maupun capaian target Macaroni Huhhah. Seperti para pesaingnya, Macaroni Huhhah melakukan komunikasi pemasaran melalui facebook, instagram, dan twitter. Promosi melalui media online dapat menjangkau lebih banyak calon konsumen dengan biaya sangat murah dibandingkan dengan promosi melalui media cetak. Manajemen pemasaran yang dilakukan Macaroni Huhhah membuahkan hasil terbukti dengan capaian target penjualan yang terus meningkat.

Keberhasilan manajemen pemasaran Macaroni Huhhah menarik untuk diteliti karena brand ini mampu mendapatkan ceruk pasar yang masih besar di tengah dominasi brand sejenis yang jauh lebih besar yaitu Macaroni Ngehe. Fakta ini menarik peneliti untuk meneliti manajemen pemasaran online Macaroni Huhhah dalam meningkatkan penjualan pada tahun 2017.

\section{KAJIAN TEORI}

\section{A. Manajemen Pemasaran}

Manajemen pemasaran adalah suatu usaha untuk merencanakan, mengimplementasikan (yang terdiri dari kegiatan mengorganisaikan, mengarahkan, mengkoordinir) serta mengawasi atau mengendalikan kegiatan pemasaran dalam suatu organisasi agar tercapai tujuan organisasi secara efesien dan efektif. Di dalam fungsi manajemen pemasaran ada kegiatan menganalisis yaitu analisis yang dilakukan untuk mengetahui pasar dan lingkungan pemasarannya, sehingga dapat diperoleh seberapa besar peluang untuk merebut pasar dan seberapa besar ancaman yang harus dihadapi. 


\section{B. Pemasaran Online}

Menurut Daryanto (2011) Pemasaran adalah Suatu proses sosial dan manajerial dimana individu dan kelompok mendapatkan kebutuhan dan keinginan mereka dengan menciptakan, menawarkan, dan bertukar sesuatu yang bernilai satu sama lain". Menurut Dharmestha (2009) Pemasaran adalah Fungsi yang memiliki kontak yang paling besar dengan lingkungan eksternal, padahal perusahaan hanya memiliki kendali yang terbatas terhadap lingkungan eksternal". Oleh karena itu, pemasaran memainkan peranan penting dalam pengembangan strategi.

\section{Instagram}

Aplikasi media sosial yang populer di kalangan pengguna telefon pintar (Smartphone) adalah instagram. Nama Instagram diambil dari kata Insta yang asalnya Instan dan gram dari kata telegram. Menurut Ghazali (2016), instagram memiliki daya tarik tersendiri bagi penggunanya karena terdapat aplikasi untuk photo-sharing dan layanan jejaring sosial online yang memungkinkan penggunanya untuk berbagi hasil foto melalui berbagai layanan social media seperti Facebook, Twitter dan situs media lainnya.

\section{METODE PENELITIAN}

\section{A. Jenis Penelitian}

Jenis penelitian ini bersifat deskriptif kualitatif yaitu prosedur penelitian yang menghasilkan data deskriptif berupa kata-kata yang tertulis dari orang-orang dan perilaku yang dapat diamati dengan cara menafsirkan fenomena yang terjadi. Metode ini dimaksudkan untuk mengungkapkan keadaan atau peristiwa sebagaimana adanya, sehingga bersifat sekadar mengungkapkan fakta yang ada. Penelitian ini akan mendeskripsikan manajemen pemasaran online Macaroni Huhhah Yogyakarta dalam meningkatkan penjualan.

\section{1) Teknik Pengumpulan Data}

a. Wawancara

Wawancara adalah salah satu bagian yang terpenting dari setiap penelitian dan dilakukan untuk memperoleh informasi dengan bertanya langsung kepada informan. Wawancara dilakukan berdasarkan pada interview guide. Wawancara ditujukan kepada:

1) Owner dan Staf Macaroni Huhhah

2) Pemilik Gerai Macaroni Huhhah

\section{b. Observasi}

Observasi merupakan teknik pengumpulan data dengan mengadakan pengamatan secara langsung. Observasi dilakukan untuk melengkapi dan memperkaya hasil pengumpulan data yang diperoleh melalui wawancara dan dokumentasi lainnya (Tjahjono, 2015).

\section{B. Teknik Analisis Data}

Analisis data yang penulis gunakan adalah analisis data kualitatif deskriptif. Teknik analis deskriptif dengan cara menggambarkan strategi promosi melalui media online secara komprehensif (keseluruhan selengkapnya secara tepat, aktual dan relevan). Data yang diperoleh, dibaca, diedit dan dianalisis kemudian diperoleh suatu kesimpulan yang signifikan. Analisis data adalah proses pengorganisasian dan mengurutkan data ke dalam pola, kategori dan satuan uraian dasar, sehingga dapat ditemukan data guna menjawab permasalahan yang diteliti.

Teknik analisis yang digunakan dalam penelitian ini adalah model interaktif models of analysis atau analisis interaktif (Miles \& Huberman, 1992). Penelitian ini bergerak diantara empat komponen data, yaitu pengumpulan data, reduksi data, penyajian data dan penarikan kesimpulan. Aktifitas ketiga komponen tersebut bukanlah linear, namun lebih merupakan siklus dalam struktur kerja interaktif. 


\section{Keabsahan Data}

Keabsahan data dalam penelitian ini dilakukan dengan teknik triangulasi data, yaitu suatu teknik pemeriksaan keabsahan data yang memanfaatkan sesuatu yang lain di luar data itu (Moleong, 2006). Guna memperoleh data yang valid dan dapat dipertanggungjawabkan maka dalam penelitian ini digunakan teknik triangulasi data, yaitu berdasar sumber, penyidikan, berdasar teori tertentu dan metode (Moleong. 2006). Triangulasi yang dipilih adalah triangulasi sumber sehingga dalam menguji keabsahan data dilakukan hanya dengan membandingkan data dari satu sumber dengan sumber yang lainnya.

Data tentang pemasaran online diuji keabsahannya dengan membandingkan informasi yang didapat dari owner dengan data dari pemilik gerai. Data tentang peningkatan hasil pemasaran diuji keabsahannya dengan membandingkan data yang didapat dari wawancara dengan data yang tercatat pada perusahaan.

\section{Lokasi Penelitian}

Penelitian ini berlokasi kantor pusat manajemen Macaroni Huhhah serta beberapa gerainya di Yogyakarta.

\section{HASIL DAN PEMBAHASAN}

\section{A. Gambaran Umum Subyek Penelitian}

\section{Produk}

Produk yang dihasilkan adalah makanan ringan makaroni dengan aneka pilihan rasa, kurang lebih ada 22 rasa, sebagian di antaranya diuraikan di bawah ini:

a) Original.

Rasa original merupakan makaroni dengan rasa asli hanya diberi tambahan rasa pedas atau gurih.

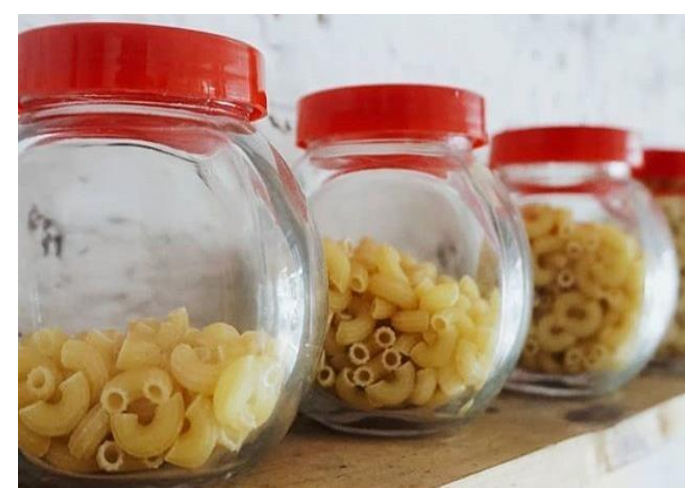

Gambar 3. Rasa Original

b) Barbeque

Sumber: @makaronihuhhahjogja

Makaroni diberi bumbu rasa barbeque yang banyak digunakan sebagai bumbu tabur diberbagai cemilan seprti keripik, dan kentang goreng. Dengan cita rasa yang menggugah selera, membuat rasa bumbu bubuk barbeque sesuai di lidah orang Indonesia.

c) Keju

Makaroni rasa keju memiliki rasa khas gurih dan asin. Variasi rasa keju ini bisa juga ditambah dengan rasa pedas 


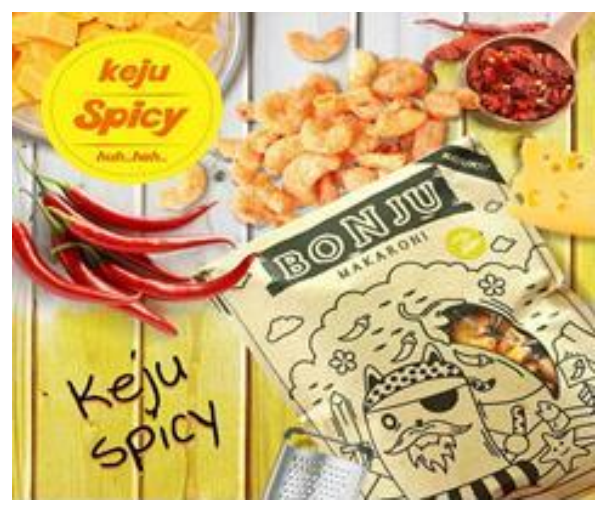

Gambar 4. Makaroni Rasa Keju

Sumber: @makaronihuhhahjogja

d) Balado

Balado adalah rasa masakan khas Minangkabau dengan bumbu yang ditumis seperti cabe giling dengan berbagai rempah, biasanya bawang merah, bawang putih, jeruk nipis. Bumbu instan yang sudah jadi digunakan untuk memberikan rasa balado pada makaroni.

e) Rumput Laut

Makaroni rasa rumput laut dihasilkan dengan cara menaburkan bumbu instan rasa rumput laut ke produk makaroni. Biasanya tetap disertai dengan rasa pedas.

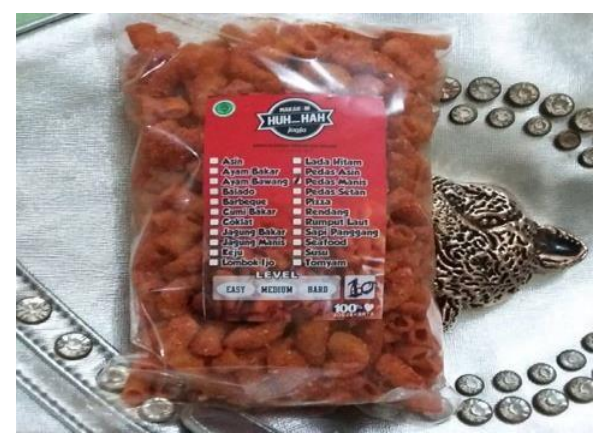

Gambar 5. Makaroni Rasa Rumput Laut

Sumber: @makaronihuhhahjogja

\section{f) Tomyam}

Makaroni rasa Tomyam bercitarasa asam, gurih, pedas. bumbu dan rempah seperti cabai kering, cabai rawit, serai, daun jeruk, dan air perasan jeruk memunculkan cita rasa gurih, asam, segar dengan sedikit gigitan pedas. Rasa ini juga didapat dari bumbu instan rasa tomyan.

g) Sapi panggang

Proses produksi dilakukan di rumah karena makaroni ini merupakan jenis industri rumah tangga. Produksi makaroni diklaim tanpa bahan pengawet dan digoreng dengan minyak goreng kemasan, bukan minyak goreng curah. Menu terdiri dari : makaroni, makaroni spiral, mie lidi, mie kriting, mie bihun, usus, basreng, potato dan makaroni basah. Harga produk tergolong murah yaitu mulai harga Rp 5000 untuk kemasan paling kecil. Adapula dengan kemasan berharga $\mathrm{Rp} 10 \mathrm{ribu}, \mathrm{Rp} 15 \mathrm{ribu}, \mathrm{Rp} 20$ ribu, dan Rp 25 ribu. Makaroni Huhhah menggunakan kemasan dengan tanda logo di bawah ini. 


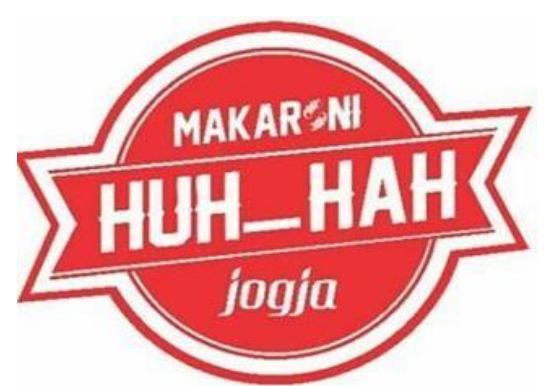

Gambar 6. Logo Makaroni Huhhah.

Sumber: @makaronihuhhahjogja

\section{B. Pembahasan}

\section{Perencanaan pemasaran}

Perencanaan merupakan penentuan segala sesuatu sebelum dilakukan kegiatankegiatan pemasaran meliputi: tujuan pemasaran, strategi pemasaran, kebijaksanaan serta taktik yang dijalankan. Tujuan pemasaran melalui instagram terutama adalah untuk mengenalkan produk, mengingatkan kepada follower tentang produk Huhhah dengan harapan untuk meningkatkan penjualan.

Strategi yang dilakukan Makaroni Huhhah untuk mencapai tujuan tersebut yaitu dengan melakukan segmentasi pasar, merancang pesan yang akan disampaikan, memilih saluran pemasaran, dan merancang bauran pemasaran. Makaroni Huhhah menetapkan segmen pasarnya yaitu konsumen usia remaja dan dewasa dari semua kalangan mulai dari kelas bawah hingga kelas atas. Pesan yang disampaikan dalam pemasaran dirancang sesuai dengan segmen pasar yaitu anak remaja dan dewasa.

Pertimbangan@makaronihuhhahjogja dalam menentukan segmentasi yaitu aspek demografis yang meliputi usia dan status ekonominya. Namun dilihat dari bahasa yang digunakan dalam instagram, segmentasi juga memperhatikan aspek gaya hidup sehingga @ makaronihuhhahjogja tidak hanya melihat aspek demografis tetapi juga aspek psikografis yang mencerminkan gaya hidup konsumen. Hal ini sejalan dengan penjelasan Tjiptono (2008) bahwa segmentasi pasar adalah proses membagi pasar keseluruhan suatu produk atau jasa yang bersifat heterogen ke dalam beberapa segmen dimana masing-masing segmen cenderung bersifat homogen dalam segala aspek.

Segmentasi pasar menjadi acuan bagi perusahaan dalam membuat suatu produk lebih spesifik dan memenuhi kebutuhan sebagian pasar yang menjadi targetnya. Dari segmentasi tersebut, Huhhah bisa menetapkan target dan posisi produknya dihadapan pesaing sehingga pesan yang disampaikan kepada target konsumen menjadi lebih tepat. Menurut Purwanto (2013) Positioning merupakan strategi yang berusaha menciptakan deferensiasi yang unik dalam bentuk pelanggan sasaran sehingga terbentuk citra atau image merk yang lebih unggul dibandingkan yang lain.

Saluran komunikasi yang dipilih yaitu instagram melalui akun @ makaronihuhhahjogja. Alasan memilih saluran melalui instagram seperti diungkap dalam kutipan wawancara dengan Arga selaku owner berikut.

Mudah banget jualan di instagram karena semua orang bahkan anak kecil sudah

memiliki gadget dan memiliki instagram. Kelebihan instagram yaitu menonjol pada unggahan gambar disertai caption. Tampilan visual memang paling mudah menarik perhatian.

Taktik yang digunakan untuk memasarkan secara gratis di instagram yaitu dengan

memperbanyak follower dan juga memfollow akun instagram orang lain. Selain itu, juga memanfaatkan semua fitur di instagram selain follower juga tagar atau hashtag yang ditandai dengan simbol pagar \#.

Bauran pemasaran yang dipilih yaitu dengan dengan menerapkan prinsip 4P yaitu product, price, place, dan promotion. Keunggulan produk dirancang sebagai keunggulan 
terletak pada produk yang bervariasi. Produk juga dikemas mulai dari kemasan terkecil dan dengan harga murah yaitu Rp 5000. Harga produk dirancang lebih murah agar dapat dijangkau oleh semua kalangan. Terkait dengan tempat layanan atau place, Makaroni Huhhah membuka beberap outlet dan melayani penjualan online melalui jasa gofood

\section{Implementasi pemasaran}

Implementasi pemasaran merupakan tindakan pemasaran untuk mencapai sasaran sesuai dengan rencana pemasaran. Implementasi ini tampak dari aktivitas sehari-hari dalam memasarkan produk melalui akun @makaronihuhhahjogja. Implementasi ini diteliti dengan mengkaji unggahan gambar atau foto produk @makaronihuhhahjogja serta bagaimana fiturfitur instagram digunakan dalam memasarkan produk.

Setidaknya, @makaronihuhhahjogja memanfaatkan fitur biodata, like, caption dan hashtag untuk memasarkan produk makaroni Huhhah.

\section{a. Penggunaan Like dan Komentar}

Fitur like terdapat di bawah unggahan di instagram untuk menandai apakah unggahan tersebut disukai follower atau tidak. Jumlah like dari followers instagram Huhhah bertambah banyak, menandakan unggahan gambar produk disukai. Dengan kata lain usaha untuk mengunggah produk berhasil dan menarik minat orang terhadap produk Huhhah. Petunjuk rasa tertarik atau rasa ingin tahu pelanggan kepada Huhhah juga dapat dilihat dari komentar positif yang diberikan followers.

Fitur likes didukung oleh fitur comments, dimana para pengguna dapat saling berinteraksi secara terbuka, bukan hanya melalui kata-kata, tetapi juga lewat emoticon. Huhhah memanfaatkan fitur-fitur secara keseluruhan sebagai alat untuk menjalin interaksi dengan publiknya, yaitu para followers. Dalam hal ini, Huhhah hanya mengunggah gambar atau video yang instagramable, yaitu haruslah jernih, jelas, dan tidak backlight, memiliki angle yang baik yang intinya adalah menarik dan layak tayang.

Fitur yang paling sering dimanfaatkan Huhhah adalah Fitur pengikut, agar dapat berinteraksi dengan sesama pengguna, sehingga aktivitas yang dilakukan dapat langsung terlihat pada timeline pengguna lain yang mengikutinya (follow). Hal ini sesuai dengan apa yang dikatakan oleh Atmoko (2012), bahwa ciri khas jejaring sosial yang paling mencolok adalah kemampuannya untuk saling follow sesama pengguna, kemudian berkomentar dan memberikan tanda suka (like) pada foto. Dengan adanya fitur ini, maka interaksi yang akan didapatkan semakin besar peluangnya seperti memberikan komentar, memberi tanda suka pada unggah tersebut, maupun mengirimkan pesan pribadi antar sesama akun yang telah saling follow.

\section{b. Biodata}

Biodata atau profil akun@makaronihuhhahjogja sangat penting untuk kepentingan bisnis. Dari profil yang lengkap, konsumen akan mudah mengenal, dan mengerti serta yakin dengan produk-produk yang ditawarkan. Biodata atau Bio terletak di bawah nama akun instagram. Pada biodata @ makaronihuhhahjogja, tidak banyak yang disajikan seperti tampak pada Gambar 7 berikut.

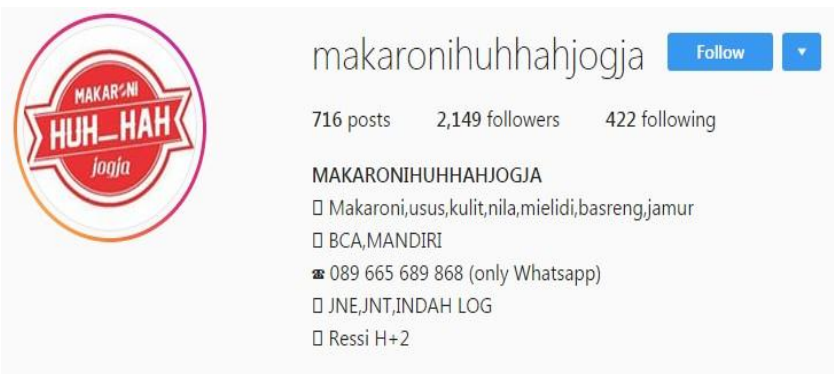

Gambar 7. Bio Huhhah

Sumber: @makaronihuhhahjogja, tahun 2018 
Biodata akun@makaronihuhhahjogja hanya menampilkan informasi macam camilan yaitu Makaroni, usus, kulit, nila, mie lidi, basreng, dan jamur. @makaronihuhhahjogja juga menampilkan bank yang dipakai Huhhah yaitu BCA dan MANDIRI, nomor kontak 089665 689868 (khusus Whatsapp), jasa pengiriman yang digunakan yaitu JNE, JNT, dan INDAH LOG.

\section{c. Hashtag}

Unggahan berupa foto atau video di @ makaronihuhhahjogja disertai dengan caption beserta tanda tagar atau hashtag (\#). Fungsi hashtag adalah untuk pengelompokan konten. Hashtag bisa digunakan dengan cara ditambahkan pada unggahan berupa teks, foto, maupun video. Dalam hal ini, owner Huhhah menjelaskan:

"Hashtag digunakan karena itu penting di setiap unggahan di kuliner karena beberapa kuliner yang followernya sudah banyak itu dikasih hashtag yang mungkin. Dengan hashtag produk akan lebih mudah dikenal orang. Saya kadang pake hashtag juga ngawur, distrojogja. Mungkin banyak netizen yang cari kuliner di jogja cari info hastag jogja."

Hashtag juga berfungsi untuk kebutuhan branding dan promosi di instagram. Dengan menggunakan hashtag yang spesial pada setiap unggahan, maka akan menjadikan ciri khas bagi sebuah brand. Hashtag yang biasa digunakan Huhhah di antaranya yaitu: \#camilankekinian, \#jajananjogja, dan \#kuliner.

Unggahan yang disertai dengan hashtag akan mudah terkumpul dengan produk sejenis. Dari hastag tersebut, unggahan Huhhah juga ada di instagram camilan kekinian, jajanan jogja dan kuliner. Netizen yang mencari kuliner jogja, jajanan jogja, camilan jogja akan dengan mudah menemukan produk Huhhah. Artinya hashtag sangat penting untuk selalu dibuat setiap kali mengunggah foto produk. Bahkan @makaronihuhhahjogja menggunakan lebih banyak hashtag seperti tampak pada Gambar 8 .
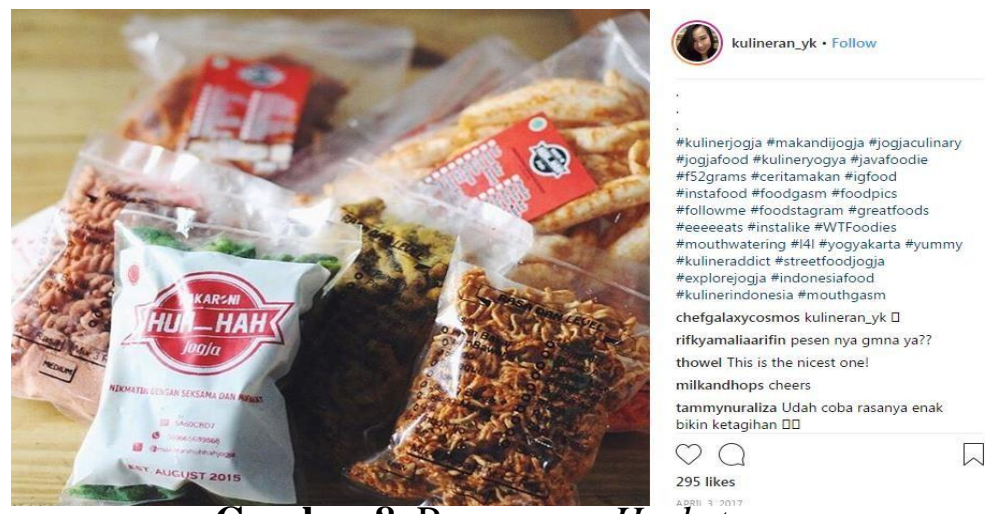

Gambar 8. Penggunan Hashstag

Sumber: @makaronihuhhahjogja, tahun 2018

Daftar hashtag yang dicantumkan dalam unggahan gambar produk pada Gambar 8 terdiri atas 28 hashtag:

$\begin{array}{lll}\text { \#kulinerjogja } & \text { \#igfood } & \text { \#mouthwatering } \\ \text { \#makandijogja } & \text { \#instafood } & \text { \#141 } \\ \text { \#jogjaculinary } & \text { \#foodgasm } & \text { \#yogyakarta } \\ \text { \#jogjafood } & \text { \#foodpics } & \text { \#yummy } \\ \text { \#kulineryogya } & \text { \#followme } & \text { \#kulineraddict } \\ \text { \#javafoodie } & \text { \#foodstagram } & \text { \#streetfoodjogja } \\ \text { \#f52grams } & \text { \#greatfoods } & \text { \#explorejogja } \\ \text { \#ceritamakan } & \text { \#eeeeeats } & \text { \#indonesiafood } \\ & \text { \#instalike } & \text { \#kulinerindonesia } \\ & \text { \#WTFoodies } & \text { \#mouthgasm }\end{array}$




\section{d. Caption}

Caption adalah deskripsi atau penjelasan singkat yang terletak di samping kanan pada gambar atau video yang diunggah. Caption berisi keterangan maupun cerita yang mewakili objek yang diunggah. Banyak dari follower maupun pengguna instagram yang tidak hanya senang pada foto atau video saja, tapi juga caption. Apapun jenis caption yang sesuai dengan foto atau kondisi hati pengguna akan mendapatkan banyak like.

Setiap kali mengunggah gambar atau video, @makaronihuhhahjogja selalu menyertakan caption semenarik dan se-komunikatif mungkin. Sejumlah contoh caption di @ makaronihuhhahjogja seperti pada Gambar 9.
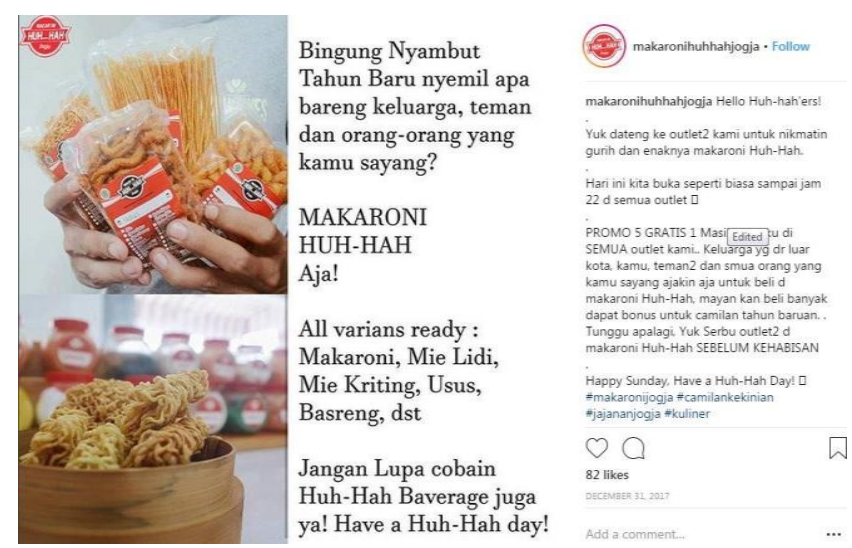

Gambar 9. Aneka Camilan Huhhah

Sumber: @makaronihuhhahjogja, tahun 2018

Caption juga dapat digunakan untuk menjelaskan meme yang diunggah. Meme itu sendiri sudah disertai dengan kalimat menarik, tapi @makaronihuhhahjogja juga merasa perlu untuk membuat caption pada unggahannya seperti tampak pada Gambar 9.

Hello Huh-hah'ers!

Yuk dateng ke outlet-outlet kami untuk nikmatin gurih dan enaknya makaroni Huh-Hah. Hari ini kita buka seperti biasa sampai jam 22 di semua outlet.

PROMO 5 GRATIS 1 Masih berlaku di SEMUA outlet kami.. Keluarga yg dr luar kota, kamu, teman2 dan smua orang yang kamu sayang ajakin aja untuk beli di makaroni Huh-Hah, mayan kan beli banyak dapat bonus untuk camilan tahun baruan.

Tunggu apalagi, Yuk Serbu outlet2 d makaroni Huh-Hah SEBELUM KEHABISAN.

Caption tidak hanya diisi dengan kata-kata yang menjelaskan produk, tetapi juga diisi dengan kalimat promo untuk menarik perhatian seperti tampak pada frase: PROMO 5 GRATIS 1. Terkait dengan penggunaan caption, owner Huhhah mengungkapkan: "kita update kata-kata yang unik dan kekiniian. Pokoknya unik dan up dating lah.”

Makaroni Huhhah melalui akun@makaronihuhhahjogja menanamkan citra produk dengan menjaga kualitas produk terutama pada kualitas rasa. Citra dalam bentuk lain juga dilakukan karena saling berkaitan seperti gerai yang unik, dan kemasan unik seperti dikemukakan dalam kutipan wawancara dengan owner Unggahan unik di instagram, outlet atau gerai yang unik, kemasan yang unik menjadi daya tarik awal konsumen untuk datang. Akan tetapi penentu akhir tetaplah pada kualitas rasa. Ketika konsumen merasa rasanya sudah tidak sesuai dengan seleranya, maka konsumen tidak akan kembali membeli. 
Menanamkan citra produk pada dasarnya sejalan dengan menumbuhkan persepsi pelanggan tentang Huhhah. Akun @makaronihuhhahjogja telah menumbuhkan persepsi pelanggan bahwa produk-produk Huhhah sangat bervariasi, banyak pilihan rasa, enak dan dengan harga murah. Citra produk berhasil dilakukan seiring dengan persepsi positif pelanggan terhadap Huhhah.

Akun@makaronihuhhahjogja membangun citra produk maupun persepi konsumen setiap saat mengunggah produk di instagram maupun pada saat bertemu langsung dengan pembeli di outlet Huhhah seperti diungkap dalam kutipan wawancara dengan owner Huhhah berikut.

"Pertamanya ya tetap diinfokan di instagram, kedua, ketika ada orang bertanya, kita sudah punya file aneka rasa yang disampaikan kepada konsumen. Huhhah unggulnya di jumlah rasa yang banyak."

Berdasarkan observasi, @ makaronihuhhahjogja juga mengunggah video di instagram untuk mengiklankan produk. Pada dasarnya, semua unggahan di instagram termasuk caption merupakan bagian dari iklan, akan tetapi unggahan video lebih banyak mendapatkan perhatian. Jumlah yang menonton video dan mengklik like jauh lebih banyak daripada sekedar unggahan gambar produk.

Fitur lain yang dimanfaatkan oleh Huhhah adalah tagar \# (hashtag), dengan tujuan untuk menandai foto dan mengelompokkannya ke dalam satu kategori tertentu (spesifik), berdasarkan kegemaran dari si pengguna. Fitur ini juga didukung oleh penggunaan Caption atau keterangan foto, yang berfungsi sebagai deskripsi dari sebuah unggahan. Pengguna dapat menambahkan kata-kata yang menggambarkan foto yang diunggah dengan dapat pula menambahkan hashtag dalam caption tersebut. Pada umumnya caption lebih bersifat untuk memperkuat karakter atau pesan yang ingin disampaikan pada foto tersebut. Panjang karakter tulisan juga tidak ditentukan atau tidak ada aturannya (Atmoko, 2012).

Implementasi pemasaran Makaroni Huhhah di instagram oleh akun @ makaronihuhhahjogja juga dilakukan dengan menerapkan bauran pemasaran yang meliputi 4P yang meliputi Product, Price, Place, dan Promotion.

\section{1) Product}

Produk Makaroni Huhhah sangat bervariasi lebih kurang sebanyak 22 rasa. Sebagaimana diulas pada bab sebelumnya, di antaranya yaitu original, barbeque, keju, rumput laut, balado, tomyam, dan sapi panggang. Variasi rasa pada produk juga memperkaya produk yang ditawarkan seperti rasa asin, manis dan pedas. Rasa pedas juga dispesifikasi menurut tingkatan rasa pedasnya. Ada rasa pedas level 1 sampai level 10.

Lopiyoadi (2013), Produk merupakan keseluruhan konsep objek atau proses yang memberikan sejumlah nilai kepada konsumen. Produk diartikan sebagai sekumpulan atribut berupa fitur, fungsi, manfaat, dan penggunaan yang digunakan untuk memberikan kepuasan konsumen (Kotler \& Keller, 2006). Produk dengan banyak variasi akan menjadikan produk lebih bernilai di hadapan konsumen. Konsumen akan merasa keinginan untuk mendapat kepuasan didaapat dari beragai variasi rasa tersebut. Daryanto \& Setyobudi (2014), menjelaskan bahwa kepuasan konsumen merupakan suatu penilaian emosional dari konsumen setelah konsumen menggunakan suatu produk, dimana harapan dan kebutuhan konsumen yang menggunakannya terpenuhi.

Produk makanan berbahan makaroni sebagai produk utama, namun juga ada produk yang berbahan non makaroni seperti mie, kulit ikan,usus dan jamur. Variasi produk yang sangat banyak ini menjadikan konsumen merasa tertarik untuk mencoba berbagai jenis produk yang ada sehingga peluang untuk repeat order akan lebih terbuka.

Pilihan kemasan dari yang terkecil dengan harga murah, variasi produk hingga 22 rasa menunjukkan kualitas produk sejalan dengan pendapat Kotler (2005) bahwa di antara indikator untuk mengukur kualitas produk yaitu variasi produk, kualitas produk, desain produk, jaminan (garansi) yang ditawarkan, merek dagang dan pembungkusan. 


\section{2) Price}

Harga produk ditetapkan dari harga satuan paling murah yaitu Rp 5000 sampai kemasan dengan harga Rp 60.000. Dengan harga yang bervariasi ini, konsumen dari kalangan bawah pun mampu membeli makaroni Huhhah. Artinya, akan lebih banyak konsumen yang membeli produk Huhhah mulai dari kelas bawah hingga kalangan ekonomi menengah atas.

Harga merupakan satu-satunya unsur bauran pemasaran yang memberikan pemasukan atau pendapatan bagi perusahaan, di samping itu merupakan unsur bauran pemasaran bersifat fleksibel (dapat cepat diubah). Stanton (1998) mendefinisikan harga adalah sejumlah uang (kemungkinan ditambah beberapa barang) yang dibutuhkan untuk memperoleh beberapa kombinasi sebuah produk dan pelayanan yang menyertainya. Tjiptono (2004) menyatakan pada dasarnya ada empat jenis tujuan penetapan harga yaitu: berorientasi pada laba, berorientasi pada volume penjualan, berorientasi pada citra, dan berorientasi pada harga.

Menurut Stanton (1998), ada empat indikator yang mencirikan harga yaitu: keterjangkauan harga, kesesuaian harga dengan kualitas produk, daya saing harga, dan kesesuaian harga dengan manfat. Dalam hal ini, telah menetapkan harga satuan terendah yaitu Rp 5000 agar dapat dijangkau oleh kelas menengah ke bawah. Selain itu, kualitas produk dijaga dengan menjaga mutu dilihat dari aspek rasa.

\section{3) Place}

Place atau penempatan mengandung pengertian tempat pelayanan yang memudahkan bagi konsumen untuk mendapatkan produk. Cara yang dilakukan yaitu dengan membuka sejumlah outlet di bawah ini.

1) Jln wates km 8,5 Pereng Dawe, Balecatur, Gamping, Sleman, YK (depan pom bensin, selatan jalan).

2) J1. Kapten Piere Tendean No.15, Wirobrajan;

3) Jl Kusumanegara 129.

4) Jl. Cinde Kembang, Klebengan, Yogyakarta.

Konsumen dapat langsung membeli di outlet-outlet tersebut. Selain itu, Makaroni Huhhah Jogja memberikan layanan pembelian online dan pengiriman produk ke luar kota sehingga konsumen tidak harus datang ke outlet. Bahkan, konsumen dari luar kota juga dapat menikmati produk Huhhah. Layanan pengiriman melalui jasa pengiriman maupun melalui gofood dikomunikasikan melalui instagram seperti tampak pada Gambar 10 disertai dengan caption seperti dikutip di bawah ini.

"Bingung ya pgn nyemil tapi panasnya very potato-potato 2 Colek abang gojek ajaa..buka aplikasi gojek, pilih menu gofood,search makaroni huhhah jogja. Pilih rasa dan level syukaa syukaa

Caption tersebut menjelaskan bahwa konsumen tidak harus datang ke outlet, tetapi juga cukup pesan melalui gojek. Dengan unggahan gambar beberapa orang gojek yang sedang antri di outlet Huhhah, maka caption tersebut memberikan penjelasan yang lebih menarik.

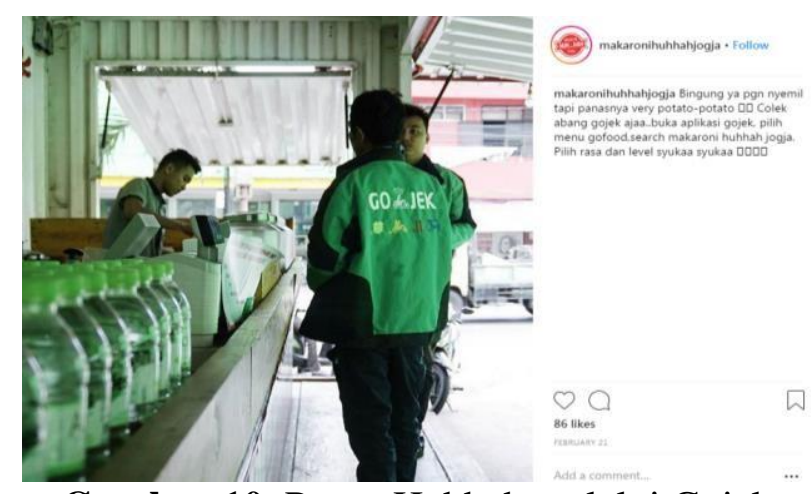

Gambar 10. Pesan Huhhah melalui Gojek

Sumber: @ makaronihuhhahjogja, tahun 2018 
Kotler and Keller (2009) menyatakan bahwa lokasi (Place) adalah suatu strategi yang menentukan dimana dan bagaimana kita menjual suatu produk tertentu. Yang terpenting dalam strategi ini adalah menetapkan lokasi, distributor atau outlet dimana konsumen dapat melihat dan membeli barang yang ditawarkan itu. Namun dengan adanya gofood dan layanan antar untuk konsumen luar kota, konsumen lebih dimudahkan tanpa harus datang ke outlet.

\section{4) Promotion}

Promosi online melalui akkun instagram @makaronihuhhahjogja menerapkan berbagai saluran pemasaran yang biasa dikenal dengan bauran pemasaran. Unggahan @makaronihuhhahjogja menampilkan iklan, pemasaran langsung, penjualan personal, promosi dan public relation.

\section{a) Iklan}

Untuk melakukan iklan, @makaronihuhhahjogja hanya menggunakan fitur di instagram gratisan, bukan instagram untuk bisnis. Iklan dengan cara gratis yaitu dengan memanfaatkan fitur hashtag yang sudah ada agar gambar-gambar yang diunggah dapat dilihat oleh lebih banyak orang. Hashtage yang dipilih harus relevan dengan produk Huhhah seperti unggahan gambar 11.

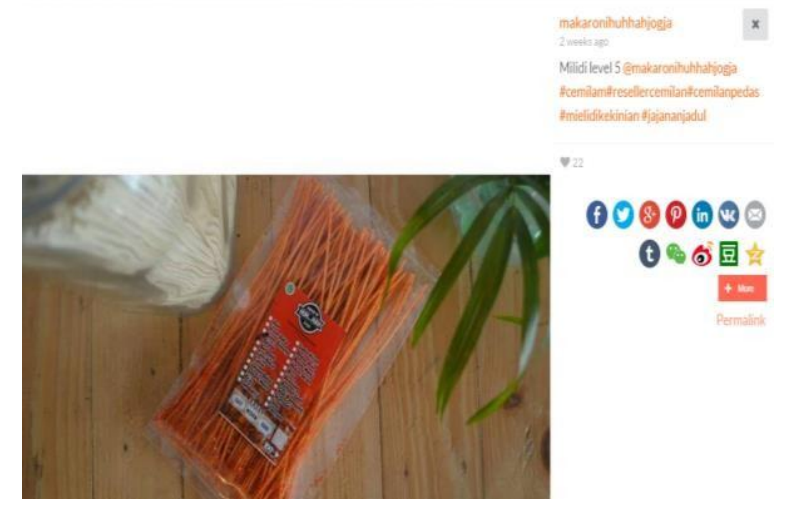

Gambar 11. Penggunaan Hashtag dalam Unggahan Produk Mielidi level 5 Sumber: @makaronihuhhahjogja, tahun 2018

Mielidi level 5 diiklankan melalui lima hashtag yaitu \#cemilam, \#resellercemilan, \#cemilanpedas, \#mielidikekinian dan \#jajananjadul sehingga produk ini dapat berada di kumpulan produk sejenis di lima hashtag tersebut. Ketika orang mencari camilan dengan menuliskan salah satu dari lima hashtage tersebut, maka orang juga akan menemukan miellidi level 5 dan dapat menuntun orang bersangkutan untuk mengunjungi @makaronihuhhahjogja. Ketika orang mencari makanan secara online dengan menuliskan tagar \#camilan, maka akan muncul Gambar 4.10 tersebut. Artinya, Gambar 4.10. juga akan bisa dilihat oleh netizen yang mencari produk dengan hashtag tersebut. Misalnya dengan menulis hashtag \#mielidikekinian maka gambar 4.10. tersebut muncul dengan tampilan seperti pada Gambar 12.
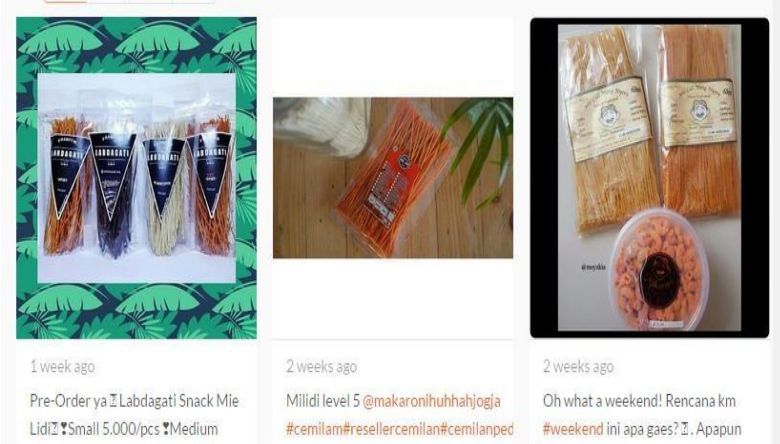

Gambar 12. Mielidi level 5 di \#mielidikekinian

Sumber: \#mielidikekinian, tahun 2018 
Iklan Huhhah juga dilakukan dengan cara menambah jumlah follower dengan cara mefollowing orang lain. Dengan men-follow akun yang memiliki banyak follower, maka pihak instagram akan melakukan sugest ke beberapa akun yang memiliki following yang sama. Dan secara tidak langsung akun Huhhah dipromosikan oleh instagram sesuai dengan kesamaan Following.

Akun@makaronihuhhahjogja juga beriklan dengan mengunggah sejumlah aktivitas orang yang senang dengan Huhhah sehingga muncul kesan banyak orang yang senang dengan Makaroni Huhhah. Unggahan gambar yang menampilkan orang-orang sedang makan atau sedang membeli Huhhah sering dilakukan oleh @makaronihuhhahjogja seperti tampak pada beberapa gambar 13 berikut.

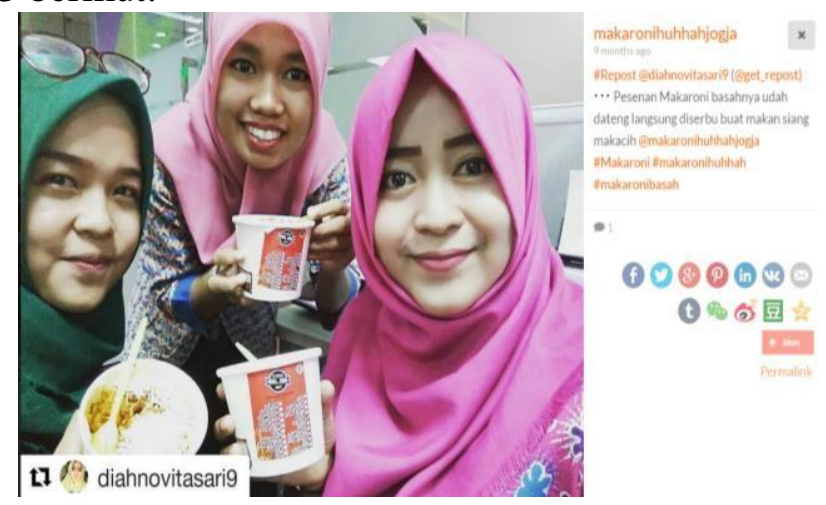

Gambar 13. Unggahan yang menampilkan Konsumen sedang Menikmati Huhhah Sumber: @ makaronihuhhahjogja, tahun 2018

Gambar 13 merupakan repost dari konsumen bernama diahnovitasari yang telah menerima kiriman produk berupa makaroni basah dari Huhhah sebagaimana tampak pada caption yang dikutip di bawah ini.

“ . . - Pesenan Makaroni basahnya udah dateng langsung diserbu buat makan siang makacih@makaronihuhhahjogja \#Makaroni \#makaronihuhhah \#makaronibasah.”

Reposting yang dilakuan @ diahnovitasari9 disadari atau tidak merupakan iklan secara sukarela oleh konsumen yang kemudian diunggah oleh @makaronihuhhahjogja. Dengan menambahkan hashtag \#Makaroni \#makaronihuhhah \#makaronibasah maka testimoni @ diahnovitasari9 akan dapat diketahui oleh lebih banyak orang.

Iklan juga dimaksudkan untuk membangun citra Makaroni Huhhah agar muncul kesan sebagai produk berkualitas, di antaranya dengan cara mencitrakan Huhhah sebagai produk yang disukai oleh orang Eropa seperti unggahan pada Gambar 14.

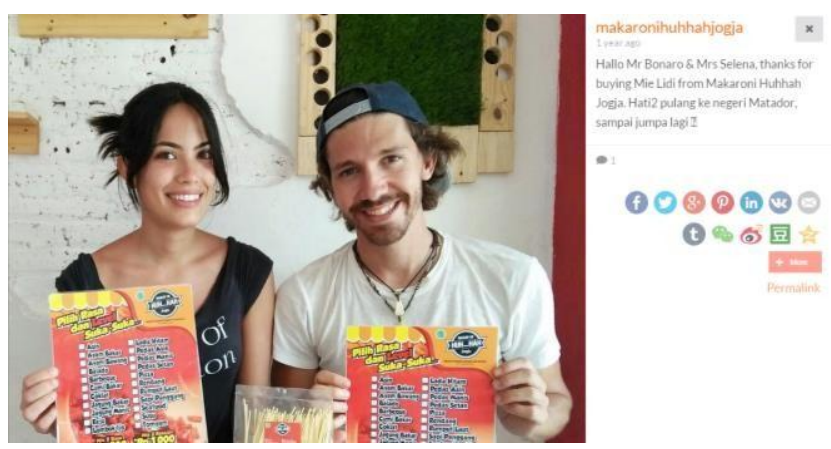

Gambar 14. Turis Asing Membeli Produk Huhhah di Outlet Sumber: @makaronihuhhahjogja, tahun 2018

Akun@makaronihuhhahjogja mengunggah gambar tersebut untuk menunjukkan bahwa produk Huhhah disukai oleh orang luar negeri. Di dalam captionnya tertulis bahwa orang luar negeri tersebut berasal dari negeri matador. 
Iklan bertujuan untuk mengenalkan produk baru sekaligus mengingatkan kepada publik dalam hal ini adalah para follower Huhhah yang berjumlah 2000 follower agar tetap mengingat atau membeli kembali produk Huhhah. Tindakan Huhhah ini sejalan dengan tujuan iklan menurut (Sulaksana, 2003) yang membagi iklan ke dalam tiga kategori yaitu iklan informatif, iklan persuasif, dan iklan untuk mengingatkan.

Minat dapat ditumbuhkan baik melalui gambar maupun caption. Menurut penelitian Surijah, dkk (2017), caption yang bersifat informasi dan persuasi lebih diminati oleh follower. Ketika akun menggunakan caption yang bersifat informatif dan mengajak follower untuk merasakan camilan Huhhah, maka persepsi yang diterima menjadi suatu indirect marketing.

Keberhasilan iklan Huhhah tidak hanya ditentukan oleh hashtag tetapi juga kualitas dari postingan maupun caption-nya agar iklan menarik minat dan mengarahkan publik yaitu para follower untuk melihatnya. Assael (2002) menjelaskan iklan yang baik harus mampu menimbulkan ketertarikan atau minat (interest), mengarahkan keputusan konsumen untuk membeli (desire) dan interest yaitu munculnya minat beli konsumen tertarik terhadap objek yang dikenalkan oleh suatu pemasar.

\section{b) Pemasaran Langsung}

Pemasaran langsung oleh @makaronihuhhahjogja tampak pada penggunaan fitur yang dipasang pada akun yang tampak dari biodata yang menampilkan nomor yang bisa dihubungi yaitu 089665689868 (only Whatsapp). Konsumen yang tertarik dapat langsung berhubungan dengan Huhhah melalui nomor whatsapp tersebut. Komunikasi juga melalui percakapan di instagram menjadikan hubungan Huhhah dengan konsumen tampak akrab sehingga dimanfaatkan untuk melakukan penawaran langsung seperti tampak pada percakapan di instagram antara admin @makaronihuhhahjogja dengan salah seorang konsumen yang kemudian diunggah di instagram pada Gambar 15 berikut.
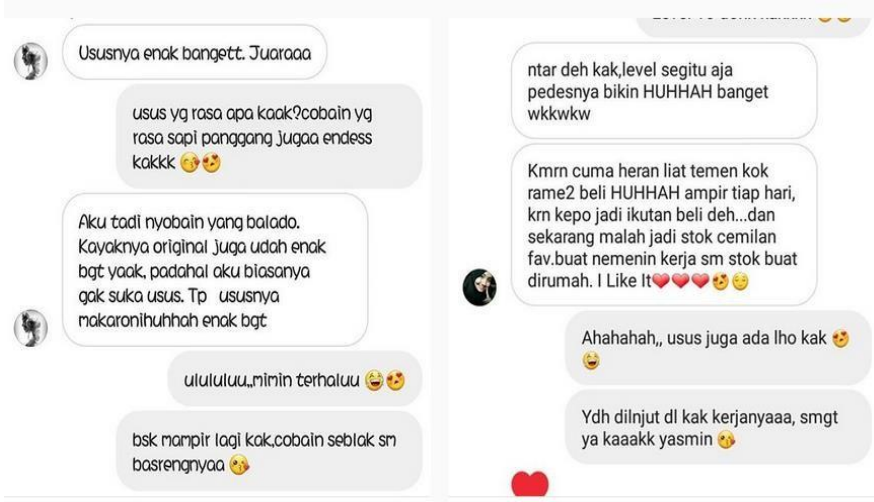

Gambar 15. Percakapan Admin dan Konsumen di instagram Sumber: @makaronihuhhahjogja, tahun 2018

Admin @makaronihuhhahjogja menawarkan produk Huhhah lainnya dengan mengatakan: "usus yang rasa apa Kak? cobain rasa sapi panggang juga endess kak." Lalu konsumen menjawab bahwa yang coba dimakan adalah makaroni rasa balado meskipun biasanya tidak suka dengan usus makaroni Huhhah. Admin @makaronihuhhahjogja kembali menawarkan produk lain dengan mengatakan: "besok mampir lagi kak, cobain seblak sama basreng." Percakapan ini memperlihatkan bahwa pemasaran langsung dapat dilakukan oleh @ makaronihuhhahjogja. Komunikasi interaktif melalui komentar di instagram juga membantu pemasaran langsung, akan tetapi biasanya tindak lanjutnya adalah tetap berkomunikasi melalui whatsaap. Hal ini menunjukkan Huhhah dalam melakukan pemasaran langsung tidak sepenuhnya melalui instagram.

Pemasaran langsung atau direct marketing adalah alat promosi yang memiliki hubungan langsung dengan konsumen individual yang ditargetkan secara cermat untuk 
memperoleh respons segera dan membangun hubungan pelanggan yang langgeng sampai penggunaan surat langsung dengan konsumen tertentu (Kottler, Amstrong, 2006). Dalam hal ini, percakapan admin Huhhah dengan konsumen dilakukan melalui pesan yang dikirim menggunakan direct message atau di whattsap.

Menurut Kotler dan Keller (2009) selain personal selling, iklan, public relations, promosi penjualan, dan public relations yang biasa dikaji, masih ada lagi jenis komunikasi yang tidak kalah penting dalam pemasaran yaitu pemasaran dari mulut ke mulut (Word of Mouth) adalah komunikasi lisan, tertulis, dan elektronik antar masyarakat yang berhubungan dengan keunggulan atau pengalaman membeli atau menggunakan produk atau jasa. Menurut Hennig-Thurau et al., (2004), Electronic Word of Mouth (e-WOM) merupakan bentuk komunikasi pemasaran yang berisi tentang pernyataan positif atau negatif yang dilakukan pelanggan potensial, pelanggan maupun mantan pelanggan tentang suatu produk atau perusahaan, yang tersedia bagi banyak orang atau lembaga melalui media Internet.

\section{c) Penjualan Personal}

Instagram tidak menyediakan fitur untuk melakukan personal selling, kecuali hanya melalui percakapan atau chatting dengan memanfaatkan komentar atau direct massage. Penjualan personal dalam arti secara personal melakukan penjualan kepada personal dapat dikatakan tidak pernah dilakukan karena tidak ada chatting penawaran atau tawar menawara harga. Penjualan personal dilakukan di outlet yaitu pada saat orang datang ke outlet, dijelaskan jenis produk baru yang menarik dan murah.

\section{d) Promosi}

Sales promotion dapat dilihat pada caption yang disertakan pada unggahan gambar produk di instagram yang menawarkan discount, gratis produk dan undian. Bentuk promosi pada instagram tampak pada caption yang diunggah di bulan Desember 2017 di bawah ini.

"Selamat pagi Huh-Hah'ers! Sdah pada cobain lezatnya mie bihun belum? Mie bihun rasanya krenyes2 enak daan pedesnya, yaampun, bikin nagih!. Yuk segera ke outlet2 terdekatnya makatoni huh-hah. Daftar promo : 1. Promo 18\% off 2. Sayembara Ig Story huhhah bagi2 voucher 25\% tiap Jumat Berkah dan Senin Ceria . Daftar outlet : 1 - jl wates km 8.5 2- jl kapt tendean no 15 wirobrajan 3- jl kusumanegara no 129 4- jl selokan mataram 99."

Caption tersebut menyebutkan adanya discount $18 \%$ dan bagi-bagi voucher $25 \%$ tiap jumat dan senin di outlet jl wates $\mathrm{km} 8.5$ 2- jl kapt tendean no 15 wirobrajan 3- jl kusumanegara no 129 4- jl selokan mataram 99. Discount dan voucher bermaksud menarik minat konsumen untuk membeli sehingga pada hari Jumat dan Senin terjadi peningkatan penjualan di outlet.

Promosi berupa pemberian produk gratis bagi konsumen yang membeli produk senilai Rp 10 ribu pada hari dan jam tertentu yang telah ditetapkan. Promosi ini tampak pada unggahan meme bertuliskan "Jumat Ceria" seperti tampak pada Gambar 16.

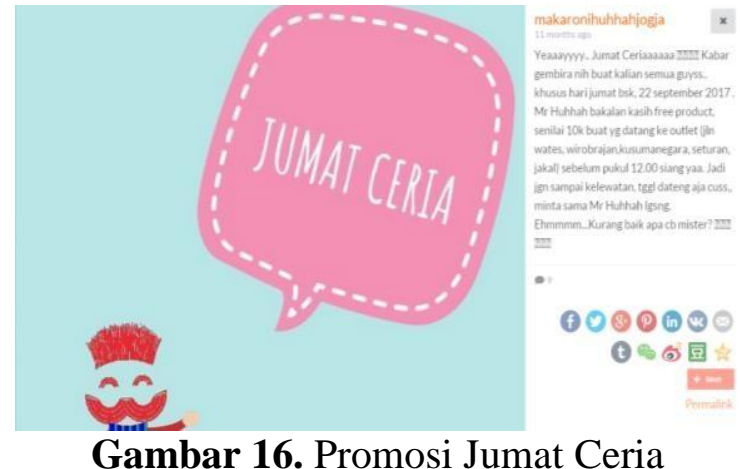

Sumber: @makaronihuhhahjogja, tahun 2018 
Caption dalam promosi Jumat ceria yang menjelaskan promosi dapat dilihat pada kutipan di bawah ini.

"Yeaaayyyy.. Jumat Ceriaaaaaa Kabar gembira nih buat kalian semua guyss.. khusus hari jumat bsk, 22 september 2017 . Mr Huhhah bakalan kasih free product, senilai 10k buat yg datang ke outlet (jln wates, wirobrajan,kusumanegara, seturan, jakal) sebelum pukul 12.00 siang yaa. Jadi jgn sampai kelewatan, tggl dateng aja cuss,, minta sama Mr Huhhah lgsng. Ehmmmm...Kurang baik apa cb mister?"

Akun@makaronihuhhahjogja menjelaskan bahwa Huhhah unggul di rasa dan harga. Dari sisi rasa Makaroni Huhhah memiki varian rasa yang lebih banyak dan tidak kalah enak dengan produk sejenis yang harganya lebih mahal. Dari sisi harga, Huhhah melakukan promosi yaitu beli lima dapat satu sedangkan produk lain mempromosikan beli 10 dapat satu.

Selain pemberian diskon atau voucer, promosi juga dengan melakukan give away seperti tampak pada unggahan Gambar 17 berikut.

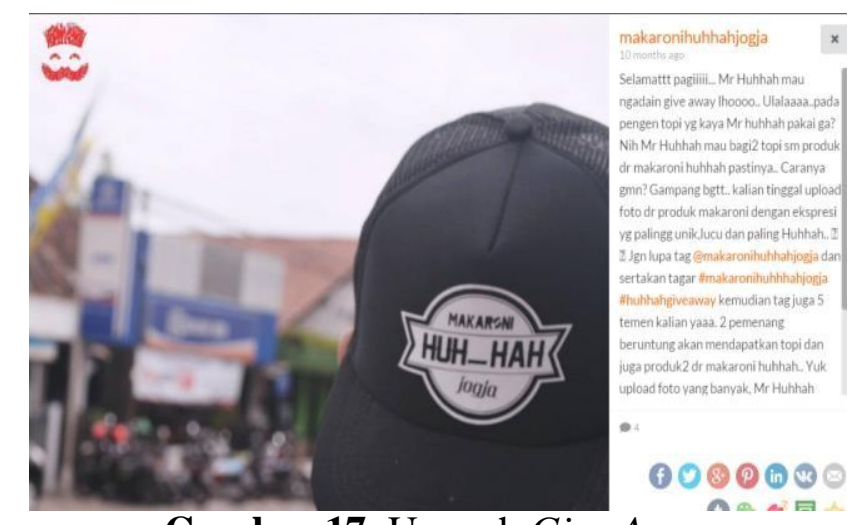

Gambar 17. Unggah Give Away

Sumber: @makaronihuhhahjogja, tahun 2018

Huhhah mengadakan give away yaitu memberikan topi berlogo Huhhah kepada pelanggan yang bersedia upload foto dari produk makaroni dengan ekspresi yang unik dan lucu disertai tagar \#makaronihuhhhahjogja \#huhhahgiveaway kemudian tag kepada 5 orang teman. Semua konsumen yang bersedia ikut akan diundi dan hanya pelanggan yang mendapat undian saja yang akan mendapatkan topi. Give away tampak pada kutipan caption berikut.

"Selamattt pagiiiii... Mr Huhhah mau ngadain give away lhoooo.. Ulalaaaa..pada pengen topi yg kaya Mr huhhah pakai ga? Nih Mr Huhhah mau bagi2 topi sm produk dr makaroni huhhah pastinya.. Caranya gmn? Gampang bgtt.. kalian tinggal upload foto dr produk makaroni dengan ekspresi yg palingg unik,lucu dan paling Huhhah.. Jgn lupa tag @makaronihuhhahjogja dan sertakan tagar \#makaronihuhhhahjogja \#huhhahgiveaway kemudian tag juga 5 temen kalian yaaa. 2 pemenang beruntung akan mendapatkan topi dan juga produk2 dr makaroni huhhah.. Yuk upload foto yang banyak, Mr Huhhah tunggu sampe tggl 1 oktober 2017 yaa.. Pengumuman pemenang pd tgl 2 oktober 2017 \#makaronihuhhahjogja \#giveaway \#giveawayjogja \#huhhahgiveaway."

Promosi yang dilakukan Huhhah sejalan dengan penjelasan Kotler dan Armstrong (2008) bahwa promosi penjualan merupakan insentif jangka pendek untuk mendorong pembelian atau penjualan sebuah produk atau jasa. Dalam hal ini, Huhhah mendorong konsumen untuk membeli lebih banyak pada hari-hari tertentu yaitu Senin dan Jumat, dan pada jam-jam tertentu. Insentif yang ditawarkan yaitu diskon, voucher, pemberian produk gratis, beli 5 dapat 1, dan give away.

Berbagai promosi penjualan tersebut bertujuan untuk menjaga agar konsumen tetap loyal pada Huhhah di samping untuk meningkatkan penjualan. Hal ini sejalan dengan pendapat Kotler \& Amstrong (2008) menyatakan bahwa tujuan digunakan promosi penjualan yaitu: menarik pembeli baru, memberi hadiah atau penghargaan kepada konsumen, 
meningkatkan daya pembelian ulang dari konsumen lama, menghindarkan konsumen lari ke merek lain, mempopulerkan merek dan meningkatkan loyalitas, meningkatkan volume penjualan jangka pendek dalam rangka "market share" jangka panjang.

\section{e) Public Relation}

Public relations tampak pada unggahan yang disesuaikan dengan waktu atau peristiwa penting seperti hari kemerdekaan RI, bulan puasa, idul adha, idul fitri, dan hari pahlawan seperti berikut ini.

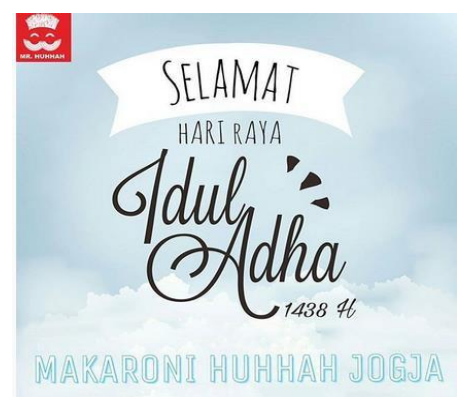

Gambar 18. Unggahan selamat idul adha 1438

Sumber: @ makaronihuhhahjogja, tahun 2017

Ucapan selamat bagi netizen dilakukan untuk menunjukkan adanya perhatian dari Huhhah bukan hanya kepada pelanggan, tetapi juga kepada netizen pada umumnya. Ucapan selamat Idul Adha, selmat Idul Fitri, merupakan bentuk perhatian terhadap konsumen.

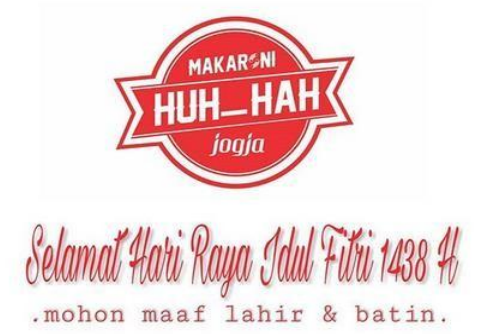

Gambar 19. Unggahan Selamat Idul Fitri 1438

Sumber: @makaronihuhhahjogja, tahun 2017

Akun@makaronihuhhahjogja melalui ucapan-ucapan selamat menunjukkan adanya perhatian terhadap konsumen atau pelanggan. Perhatian ini berimplikasi langsung atau tidak langsung terhadap perhatian masyarakat terhadap Huhhah.

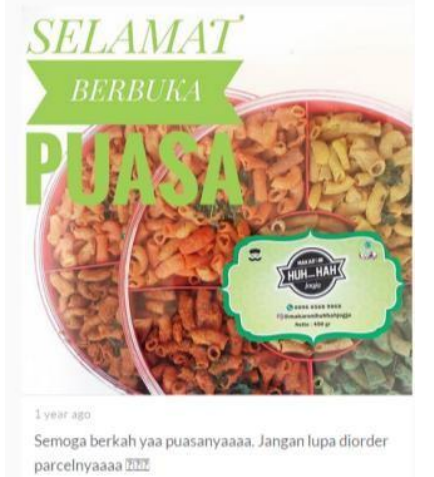

Gambar 20. Unggahan Ucapan Selamat Berbuka Puasa

Sumber: @makaronihuhhahjogja, tahun 2017 
Public relations di instagram dilakukan dengan mengunggah gambar dengan caption yang menunjukkan kepedulian Makaroni Huhhah terhadap masyarakat pada umumnya, terutama kepada konsumen. Hal ini seperti tampak dalam caption pada Gambar 20.

"Gmn Hari Jumat Kalian genk? Smga ttep lancar dan berkah yaaaa Nah udh sore aja nih.. pas bgt plg dr aktivitas mampir beli cemilan di Makaroni Huhhah donk.. Buat prepare weekend kalian yg pastinya tambah azieeekk kl smbil cemil yg pedes2 Yuk yuk yukkk,, serbuuuuu Mr Huhhah skrg juga, ada promo pembelian 5pcs dapet free 1 lho. Jgn sampai kehabisan promonya".

Caption tersebut menunjukkan adanya kepedulian Makaroni Huhhah terhadap aktivitas konsumen dan acara libur akhir pekan sekaligus mengingatkan adanya promo beli 5 dapat free 1 .

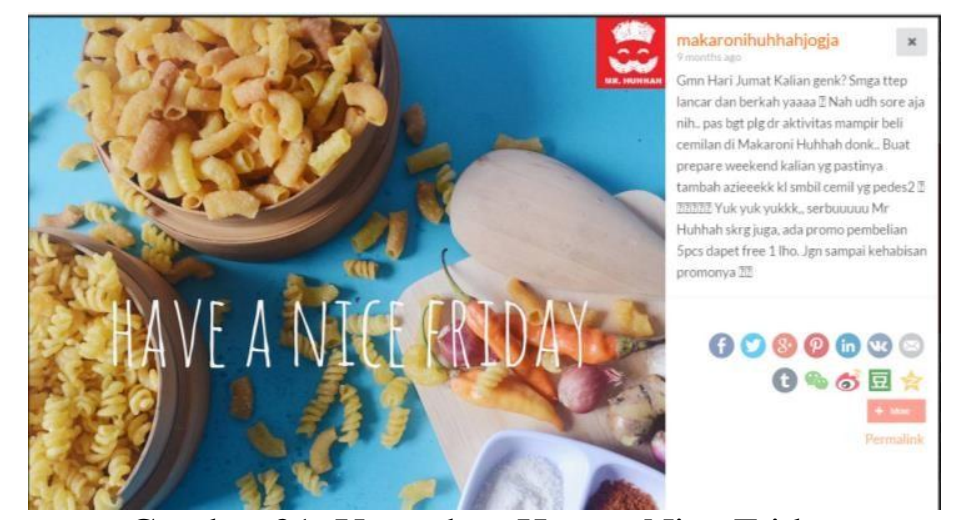

Gambar 21. Unggahan Have a Nice Friday

Sumber: @ makaronihuhhahjogja, tahun 2018

Tindakan Huhhah tersebut sejalan dengan pendapat Kotler (2005), bahwa public relations mempunyai tujuan membangun kesadaran, membangun kredibilitas dan mengurangi biaya promosi. Public relations dapat membangun kesadaran dengan menempatkan cerita di media untuk menarik perhatian orang terhadap suatu produk, jasa, organisasi, atau ide. Public relations dapat menambah kredibilitas dengan mengkomunikasikan pesan. Public relations membutuhkan lebih sedikit biaya daripada pos langsung dan media iklan semakin kuat alasan menggunakan public relations untuk memperoleh perhatian.

\section{Pengawasan dan Pengendalian}

Pengendalian merupakan usaha memberikan petunjuk pada para pelaksana agar mereka selalu bertindak sesuai dengan rencana, meliputi: penentuan standard, supervisi kegiatan atau pemeriksaan, perbandingan hasil dengan standard, dan kegiatan mengkoreksi standard (Shinta, 2011). Pengendalian dilakukan selama kegiatan implementasi. Hal ini dapat dilihat dari tindakan untuk selalu melakukan perbaikan sesuai dengan dinamika pemasaran. Sebagai contoh, terkait dengan harga dan promosi penjualan. Untuk meningkatkan penjualan pada hari-hari tertentu, Makaroni Huhhah memberikan diskon.

Pemasaran melalui instagram secara garis besar dilakuan dengan mengunggah foto produk disertai dengan caption. Unggahan disertai dengan menggunakan hashtag. Pihak manajemen dalam hal ini admin akun @makaronihuhhahjogja akan mencermati respon publik. Jika hanya sedikit respon akan dibuat lagi foto-foto produk dan diunggah dengan hashtag yang relevan dan lebih banyak lagi.

pengawasan sebagai mendeterminasi apa yang telah di laksanakan,artinya mengevaluasi prestasi kerja dan apabila perlu, dengan menerapkan tindakan-tindakan korektif sehingga hasil pekerjaan sesuai rencana yang telah di tetapkan (George, 2006) pengawasan macaroni huhhah di lakukan dengan cara evaluasi tim persatu bulan sekali setiap akhir bulan, mulai dari evaluasi sumber daya manusia, kualitas produk, kebersihan outlet dan pelayanan di outlet. 
Pembahasan terhadap hasil penelitian dan pengujian yang diperoleh disajikan dalam bentuk uraian teoritik, baik secara kualitatif maupun kuantitatif. Hasil percobaan sebaiknya ditampilkan dalam berupa grafik atau pun tabel.

\section{KESIMPULAN}

Hasil penelitian dan pembahasan pada bab sebelumnya dapat diambil kesimpulan bahwa manajemen pemasaran Makaroni Huhhah secara online melalui instagram dilakukan dengan terlebih dulu membuat perencanaan lalu diimplementasikan. Agar mencapai tujuannya, manajemen pemasaran dilakukan dengan tetap melakukan pengawasan dan pengendalian terhadap kegiatan pemasaran.

\section{Perencanaan pemasaran.}

Perencanaan pemasaran meliputi penentuan segmen pasar, pemilihan saluran komunikasi pemasaran, penentuan tujuan pemasaran, penentuan strategi pemasaran yaitu menggunakan instagram, dan menentukan bauran pemasaran. Segmen pasar Makaroni Huhhah yaitu anak remaja dan dewasa dari semua lapisan masyarakat.

\section{Implementasi pemasaran}

Implementasi meliputi semua aktivitas untuk merealisasikan rencana pemasaran yang sudah disusun. Pemasaran secara online melalui akun instagram @makaronihuhhahjogja bertujuan untuk mengenalkan produk dan mengingatkan kepada publik bahwa makaroni Huhhah tetap eksis dengan tujuan akhir yaitu terjadinya penjualan.

Strategi pemasaran yang dilakukan yaitu dengan memanfaatkan fitur yang ada di instagram. @makaronihuhhahjogja mengunggah foto produk disertai dengan caption untuk menarik perhatian follower. Dengan follower sebanyak 2000 akun maka unggahan dapat diakses oleh follower. Selain itu, @makaronihuhhahjogja mengunggah dengang menuliskan tagar atau hashtag agar unggahan dapat menyebar di kumpulan unggahan dengan hashtag yang sama. Jumlah like pada setiap unggahan menunjukkan adanya respon terhadap produk yang diunggah di instagram.

Strategi pemasaran juga memanfaatkan bauran pemasaran yang meliputi product, price, place, dan promotion. Dari sisi produk, Makaroni Huhhah menyediakan 22 variasi rasa sehingga selera konsumen yang beragam dapat terlayani. Konsumen juga merasa produk Makaroni Huhhah sesuai dengan seleranya. Dari sisi harga (price), Makaroni Huhhah mengemas produk dengan kemasan paling murah yaitu Rp 5000 hingga Rp 60.000 sehingga konsumen dari kelas menengah bawah tetap mampu membeli produk Makaroni Huhhah. Dari sisi tempat layanan atau akses, Makaroni Huhhah telah menyediakan empat outlet dan melayani pembelian menggunakan jasa gofood sehingga konsumen tidak harus datang ke outlet tetapi cukup membeli dari rumah melalui aplikasi gofood. Dari sisi promosi, Makaroni Huhhah melalui @makaronihuhhahjogja melalukan bauran promosi yang meliputi iklan, pemasaran langsung, promosi penjualan, dan public relation. Iklan dilakukan dengan memanfaatkan caption, hashtag dan followers. Pemasaran langsung pada instagram dengan menuliskan caption yang menawarkan produk secara langsung kepada para followernya. Promosi penjualan tampak dari caption yang menerangkan adanya diskon, pemberian gratis pada hari Jumat dan give away atau semacam pemberian hadiah bagi followers yang telah bersedia mengikuti atau melakukan permintaan @ makaronihuhhahjogja.

\section{Pengawasan dan Pengendalian}

Pengawasan dan pengendalian dilakukan dengan cara melihat like, komentar ataupun direct massage. Jika respon dirasa kurang, maka admin @makaronihuhhahjogja akan mengunggah foto produk dengan caption yang lebih menarik dan menggunakan hashtag yang relevan dan dengan jumlah hashtag yang lebih banyak. 


\section{SARAN}

a. Terkait dengan produk, Makaroni Huhhah dapat memperkaya komoditas dengan produkproduk camilan sejenis.

b. Terkait promosi online, Makaroni Huhhah sebaiknya menggunakan instagram adv yang merupakan instagram yang memiliki banyak fitur untuk mendukung bisnis online.

c. Terkait dengan iklan, admin @ makaronihuhhahjogja sebaiknya meningkatkan frekuensi iklan dengan memperhatikan hashtag yang relevan dan sedang ramai.

\section{DAFTAR PUSTAKA}

Assael, H., (2002), Consumer Behavior and Marketing Action. Fourth Edition. Boston: PWS-Kent Publishing Company

Atmoko, B.D., (2012), Instagram Handbook. Jakarta: PT. Trans Media.

Daryanto, (2011), Manajemen Pemasaran: Sari Kuliah. Bandung: Satu Nusa.

Daryanto, dan Setyobudi., (2014), Konsumen dan Pelayanan Prima. Gava Media: Yogyakarta

Dharmesta, B.S., (2009), Manajemen Pemasaran modern, ke-5, Yogyakarta Liberty.

George, R.T., (2006), Principles of Management. (Alih bahasa winardi), Alumni Bandung.

Ghazali, M., (2016), Buat Duit Dengan Facebook dan Instagram : Panduan Menjana Pendapatan dengan Facebook dan Instagram, Malaysia: Publishing House.

Hennig-Thurau, T ., Gwinner, K.P., Walsh, G. dan Gremler, D.D., (2004), Electronic Word-ofMouth Via Customer-Opinion Platforms: What Motivates Consumer to Articulate Themselves on the Internet. Journal of Interactive Marketing, Vol 18/No 1, 38-52.

Kotler, P., \& Keller, K.L., (2009), Manajemen pemasaran. Edisi 13 Jilid 1. Jakarta: Ghalia Indonesia

Kotler, P., (2005), Marketing Management Analysis, Planning, Implementation, and Control, The millenium edition, Englewood Cliffs, NNJ: Prentice Hall, Inc.

Kotler, P., (2008), Manajemen Pemasaran Edisi 12 Jilid 2. Jakarta: Indeks

Kotler, P., dan Armstrong, A., (2008), Prinsip-prinsip Pemasaran, Edisi 12, Jilid ke-1, Jakarta : Penerbit Erlangga

Kotler, P., dan Keller, K.L., (2006). Marketing Management, twelfth Ed. New Jersey: Pearson Prentice Hall, Upper Saddle River.

Lopiyoadi, (2013), Manajemen Pemasaran Jasa Berbasis Kompetensi. Edisi Ketiga. Salemba: Jakarta.

Miles, M.B. dan Huberman., A.M., (1992), Analisa Data Kualitatif. Buku Sumber Tentang MetodeMetode Baru. Jakarta, Universitas Indonesia (UI Press).

Moleong, J.L., (2006), Metode Penelitian Kualitatif, PT. Remaja Rosdakarya, Bandung.

Purwanto, (2013), Komunikasi Bisnis. Jakarta: Erlangga

Rangkuti, F., (2009), Strategi Promosi yanga Efektif, Jakarta: Gramedia.

Shinta, A., (2011), Ilmu Usahatani. Universitas Brawijaya Press, Malang.

Stanton, W.J., (1998), Prinsip Pemasaran Edisi Ketujuh Jilid 1 . Jakarta: Erlangga

Sulaksana, U., (2003), Integrated Marketing Communication, Pustaka Pelajar, Yogyakarta.

Surijah, E.A., Kirana, C.T., dkk, (2017), Membedah Instagram: Analisis Isi Media Sosial Pariwisata Bali, Intuisi Jurnal Psikologi Ilmiah, 9 (1), 1-17.

Tjahjono, H.K (2015), Metode Penelitian Bisnis. VSM MM UMY

Tjiptono, A., (2008). Strategi Bisnis Pemasaran. Andi, Yogyakarta. 